\title{
Dyella ginsengisoli sp. nov., isolated from soil of a ginseng field in South Korea
}

\author{
Correspondence \\ Wan-Taek Im \\ wandra@kaist.ac.kr \\ Sung-Taik Lee \\ e_stlee@kaist.ac.kr
}

\author{
Hae-Min Jung, ${ }^{1}$ Leonid N. Ten, ${ }^{2}$ Kyoung-Ho Kim, ${ }^{1} \dagger$ Dong Shan An, ${ }^{1}$ \\ Wan-Taek $\mathrm{Im}^{1}$ and Sung-Taik Lee ${ }^{1}$
${ }^{1}$ Department of Biological Sciences, Korea Advanced Institute of Science and Technology, 373-1 Guseong-dong, Yuseong-gu, Daejeon 305-701, Republic of Korea Daejeon 302-735, Republic of Korea \\ ${ }^{2}$ Department of Biology and Medicinal Science, Pai Chai University, 14 Yeonja-1-Gil, Seo-Gu,
}

\begin{abstract}
A Gram-negative, aerobic, yellow-pigmented, non-spore-forming, motile, rod-shaped bacterium, designated strain Gsoil $3046^{\top}$, was isolated from soil from a ginseng field in Pocheon Province, South Korea, and was characterized taxonomically by using a polyphasic approach. A comparative analysis of $16 \mathrm{~S}$ rRNA gene sequences revealed that strain Gsoil $3046^{\top}$ belongs to the family Xanthomonadaceae in the Gammaproteobacteria. The greatest sequence similarity was found with respect to Dyella koreensis KCTC $12359^{\top}(97.7 \%)$, Dyella japonica IAM $15069^{\top}(97.4 \%)$, Frateuria aurantia DSM $6220^{\top}(96.7 \%)$, Fulvimonas soli LMG $19981^{\top}(96.2 \%)$ and Luteibacter rhizovicinus DSM $16549^{\top}(96.0 \%)$. The phylogenetic distances from other recognized species within the family Xanthomonadaceae, including Dyella yeojuensis KACC $11405^{\top}$, were greater than $4.0 \%$ (i.e. the sequence similarities were less than $96.0 \%$ ). DNA-DNA hybridization experiments showed that the levels of DNA-DNA relatedness between strain Gsoil $3046^{\top}$ and its phylogenetically closest neighbours were below $25 \%$. The $G+C$ content of the genomic DNA was $66.6 \mathrm{~mol} \%$. In addition, the presence of ubiquinone Q-8 as the predominant respiratory quinone, iso- $\mathrm{C}_{17: 1} \omega 9 \mathrm{c}$, iso- $\mathrm{C}_{16: 0}$, iso- $\mathrm{C}_{15: 0}$ and iso- $\mathrm{C}_{17: 0}$ as the major cellular fatty acids and iso- $\mathrm{C}_{13: 0} 3-\mathrm{OH}$ and iso- $\mathrm{C}_{11: 0} 3-\mathrm{OH}$ as the major hydroxy fatty acids supported the affiliation of strain Gsoil $3046^{\top}$ to the genus Dyella. On the basis of its phenotypic properties and phylogenetic distinctiveness, strain Gsoil $3046^{\top}$ represents a novel species in the genus Dyella, for which the name Dyella ginsengisoli sp. nov. is proposed. The type strain is Gsoil $3046^{\top}$ $\left(=\right.$ KCTC $12599^{\top}=$ DSM $\left.18387^{\top}\right)$.
\end{abstract}

Xie \& Yokota (2005) isolated three bacterial strains from garden soil and proposed that they represented a novel genus, Dyella, with Dyella japonica as the type species. Cells of the isolates were Gram-negative, yellow-coloured, rodshaped, catalase-positive and urease-negative. These strains were shown to be distinguishable from representatives of other genera within the family Xanthomonadaceae of the Gammaproteobacteria [i.e. Frateuria aurantia (Swings et al., 1984), Fulvimonas soli (Mergaert et al., 2002) and Rhodanobacter lindaniclasticus (Nalin et al., 1999)]. In addition to $D$. japonica, there are currently two other species with validly published names, namely Dyella koreensis (An et al., 2005) and Dyella yeojuensis (Kim et al., 2006).

tPresent address: Korean Collection for Type Cultures (KCTC), Korea Research Institute of Bioscience and Biotechnology, 52 Oeundong, Yusong-gu, Daejeon 305-333, Republic of Korea.

The GenBank/EMBL/DDBJ accession number for the 16S rRNA gene sequence of strain Gsoil $3046^{\top}$ is $A B 245367$.
During the course of a study on the culturable bacterial community living in the soil of a ginseng field in Pocheon Province (South Korea), a large number of novel bacterial strains were isolated (Im et al., 2005). One of these strains, designated Gsoil $3046^{\mathrm{T}}$, was subjected to taxonomic characterization and 16S rRNA gene sequence analysis: on the basis of the data from these investigations, the strain was found to belong to the genus Dyella. The results from phenotypic, chemotaxonomic and phylogenetic analyses, in combination with the data from DNA-DNA hybridization experiments, showed that Gsoil $3046^{\mathrm{T}}$ represents a novel species of the genus Dyella.

The soil sample from which strain Gsoil $3046^{\mathrm{T}}$ was obtained was thoroughly suspended in $50 \mathrm{mM}$ phosphate buffer ( $\mathrm{pH}$ 7.0) and serial decimal dilutions of the suspension were spread onto a modified version of R2A solid medium containing the following $\left(1^{-1}\right): 0.25 \mathrm{~g}$ tryptone, $0.25 \mathrm{~g}$ peptone, $0.25 \mathrm{~g}$ yeast extract, $0.125 \mathrm{~g}$ malt extract, $0.125 \mathrm{~g}$ beef extract, $0.25 \mathrm{~g}$ Casamino acids, $0.25 \mathrm{~g}$ Soytone (Difco), $0.5 \mathrm{~g}$ glucose, $0.3 \mathrm{~g}$ soluble starch, $0.2 \mathrm{~g}$ 
xylan, $0.3 \mathrm{~g}$ sodium pyruvate, $0.3 \mathrm{~g} \mathrm{~K}_{2} \mathrm{HPO}_{4}, 0.05 \mathrm{~g}$ $\mathrm{MgSO}_{4}, 0.05 \mathrm{~g} \mathrm{CaCl}_{2}$ and $15 \mathrm{~g}$ agar. The plates were incubated at $30{ }^{\circ} \mathrm{C}$ for 2 weeks. Single colonies on the plates were purified by transferring them onto fresh plates of the modified R2A agar for further incubation. Purified colonies were tentatively identified from partial sequences of the 16S rRNA gene (Im et al., 2005). One isolate, Gsoil $3046^{\mathrm{T}}$, was cultured routinely on R2A agar (Difco) at $30{ }^{\circ} \mathrm{C}$ and preserved in a glycerol solution $(20 \%, \mathrm{w} / \mathrm{v})$ at $-70{ }^{\circ} \mathrm{C}$.

The Gram reaction was performed using the non-staining method, as described by Buck (1982). Cell morphology and motility were investigated under a Nikon light microscope ( $\times 1000$ magnification) using the hanging drop technique with cells allowed to grow on R2A agar for 3 days at $30{ }^{\circ} \mathrm{C}$. Catalase activity was determined by assessing bubble production in $3 \%(\mathrm{v} / \mathrm{v}) \mathrm{H}_{2} \mathrm{O}_{2}$ and oxidase activity was determined using $1 \%(\mathrm{w} / \mathrm{v})$ tetramethyl-p-phenylenediamine. Enzyme activities and other physiological and biochemical characteristics were determined with API ZYM, API 20NE and API $50 \mathrm{CH}$ galleries (bioMérieux). Tests involving commercial systems were generally performed according to the manufacturer's instructions and under the same conditions as those described by Kim et al. (2006). In addition to analysis using API 20NE, the assimilation of other substrates as sole carbon sources was determined, as described by Ten et al. (2006). Anaerobic growth was determined under a nitrogen atmosphere in serum bottles containing R2A broth (Difco) supplemented with thioglycolate $\left(1 \mathrm{~g} \mathrm{l}^{-1}\right)$. Degradation of DNA (DNase activity) was tested using DNase agar (Scharlau) and flooding plates with $1 \mathrm{M} \mathrm{HCl}$; results were evaluated after 5 days. Tests for degradation of casein, chitin, starch (Atlas, 1993), lipid (Kouker \& Jaeger, 1987), xylan (Ten et al., 2004) and cellulose (Ten et al., 2004) were also evaluated after 5 days. Growth at various temperatures $(4,15,20,25,30,37$, 42,45 and $\left.50{ }^{\circ} \mathrm{C}\right)$ and $\mathrm{pH}$ values $(\mathrm{pH} 4.5-10.0$, using increments of $0.5 \mathrm{pH}$ units) was assessed after 5 days incubation. Salt tolerance was tested on R2A agar supplemented with $1-10 \%(\mathrm{w} / \mathrm{v}) \mathrm{NaCl}$ after 5 days incubation.

For the phylogenetic analysis of strain Gsoil $3046^{\mathrm{T}}$, genomic DNA was extracted using a commercial genomic DNA-extraction kit (Solgent) and PCR-mediated amplification of the 16S rRNA gene and sequencing of the purified PCR product were carried out according to Kim et al. (2005). Full sequences of the $16 \mathrm{~S}$ rRNA gene were compiled using SeqMan software (DNASTAR). The $16 \mathrm{~S}$ rRNA gene sequences of related taxa were obtained from GenBank. Multiple alignments were performed with the CLUSTAL_X program (Thompson et al., 1997) and gaps were edited in the BioEdit program (Hall, 1999). Evolutionary distances were calculated using the Kimura two-parameter model (Kimura, 1983). The phylogenetic trees were constructed by using the neighbour-joining (Saitou \& Nei, 1987) and maximum-parsimony (Fitch, 1971) methods with the MEGA3 program (Kumar et al., 2004); bootstrap analyses were based on 1000 replications (Felsenstein, 1985).
For measurement of the $\mathrm{G}+\mathrm{C}$ content of the chromosomal DNA, genomic DNA of strain Gsoil $3046^{\mathrm{T}}$ was extracted and purified as described by Moore \& Dowhan (1995) and enzymically degraded into nucleosides. The $\mathrm{G}+\mathrm{C}$ content was then determined as described by Mesbah et al. (1989), using reversed-phase HPLC. Isoprenoid quinones were extracted with chloroform/methanol $(2: 1, \mathrm{v} / \mathrm{v})$, evaporated under a vacuum and re-extracted in n-hexane-water $(1: 1$, $\mathrm{v} / \mathrm{v}$ ). The crude quinone in $\mathrm{n}$-hexane solution was purified using Sep-Pak Vac silica cartridges (Waters) and analysed subsequently using HPLC, as described by Hiraishi et al. (1996). The cellular fatty acid profile was determined for strain Gsoil $3046^{\mathrm{T}}$ grown on R2A agar for $48 \mathrm{~h}$. The cellular fatty acids were saponified, methylated and extracted according to the protocol of the Sherlock Microbial Identification System (MIDI). The fatty acid methyl esters were then analysed by means of gas chromatography (model 6890; Hewlett Packard) using the Microbial Identification software package (Sasser, 1990). The value range was obtained using duplicate experiments.

Cells of strain Gsoil $3046^{\mathrm{T}}$ were Gram-negative, aerobic, motile and rod-shaped $(0.2-0.5 \mu \mathrm{m}$ wide and $1.5-2.1 \mu \mathrm{m}$ long). After 3 days growth on R2A agar, colonies were 1.0$3.0 \mathrm{~mm}$ in diameter, yellow-pigmented, smooth, circular, entire and transparent with clear edges. On R2A agar, the optimal temperature for growth for the isolate was $30{ }^{\circ} \mathrm{C}$; growth occurred at $15-42{ }^{\circ} \mathrm{C}$, but not at 4 or $45^{\circ} \mathrm{C}$. Like recognized species of the genus Dyella, strain Gsoil $3046^{\mathrm{T}}$ was positive for catalase, alkaline phosphatase, leucine arylamidase, valine arylamidase, D-glucose assimilation and acid production from D-glucose and D-fucose, but negative for arginine dihydrolase, urease and indole production. Phenotypic and chemotaxonomic characteristics that serve to differentiate strain Gsoil $3046^{\mathrm{T}}$ from recognized Dyella species and Frateuria aurantia are listed in Table 1. In particular, strain Gsoil $3046^{\mathrm{T}}$ could be readily differentiated from the above-mentioned species from its ability to produce $\alpha$-mannosidase, its ability to produce acid from arbutin, by the absence of esterase (C4) activity and by the absence of acid production from D-mannose and Dgalactose.

The 16S rRNA gene sequence of strain Gsoil $3046^{\mathrm{T}}$ was a continuous stretch of $1491 \mathrm{bp}$ (base position 27-1512 with respect to the Escherichia coli numbering system). Comparative 16S rRNA gene sequence analyses showed that strain Gsoil $3046^{\mathrm{T}}$ is phylogenetically affiliated with species of the genus Dyella. Phylogenetic trees obtained using neighbour-joining and maximum-parsimony methods placed strain Gsoil $3046^{\mathrm{T}}$ in a distinct position within the radiation of the genus Dyella (Fig. 1). On the basis of $16 \mathrm{~S}$ rRNA gene sequence similarities, the closest phylogenetic neighbours of strain Gsoil $3046^{\mathrm{T}}$ were $D$. koreensis KCTC $12359^{\mathrm{T}}$ (97.7\% similarity), D. japonica IAM $15069^{\mathrm{T}}$ (97.4\%), Frateuria aurantia DSM $6220^{\mathrm{T}} \quad(96.7 \%)$, Fulvimonas soli LMG $19981^{\mathrm{T}}(96.2 \%)$ and Luteibacter rhizovicinus DSM $16549^{\mathrm{T}}(96.0 \%)$. The phylogenetic 
Table 1. Differential characteristics of strain Gsoil $3046^{\top}$ (Dyella ginsengisoli sp. nov.) and members of the genera Dyella and Frateuria

Strains: 1, Gsoil $3046^{\mathrm{T}}$ (data from this study); 2, D. koreensis KCTC $12359^{\mathrm{T}} ; 3$, D. japonica IAM $15069^{\mathrm{T}} ; 4$, D. yeojuensis $\mathrm{KACC}_{11405^{\mathrm{T}}}$; 5 , Frateuria aurantia DSM $6220^{\mathrm{T}}$. All data for taxa 2-5 are from Kim et al. (2006), except where indicated otherwise. All strains are positive for alkaline phosphatase, esterase lipase (C8), leucine arylamidase, valine arylamidase and naphthol-AS-BI-phosphohydrolase activities (API ZYM). All strains are negative for lipase (C14), trypsin, $\alpha$-chymotrypsin and $\beta$-glucuronidase activities (API ZYM) and for indole production and arginine dihydrolase and urease activities (API 20NE). All strains utilize D-glucose and do not assimilate L-arabinose, D-mannitol, gluconate, caprate, adipate, citrate or phenyl acetate. All strains produce acids from D-glucose and D-fucose and do not produce acids from glycerol, erythritol, Darabinose, L-xylose, D-adonitol, methyl $\beta$-D-xylopyranoside, L-sorbose, L-rhamnose, dulcitol, D-mannitol, D-sorbitol, methyl $\alpha$-D-mannopyranoside, methyl $\alpha$-D-glucopyranoside, $N$-acetylglucosamine, amygdalin, salicin, D-lactose, melibiose, sucrose, inulin, melezitose, raffinose, glycogen, xylitol, gentiobiose, turanose, D-lyxose, D-tagatose, L-fucose, D-arabitol, L-arabitol, gluconate, 2-ketogluconate or 5-ketogluconate. +, Positive; -, negative; w, weakly positive.

\begin{tabular}{|c|c|c|c|c|c|}
\hline Characteristic & 1 & 2 & 3 & 4 & 5 \\
\hline Motility & + & $-{ }^{*}$ & $+\dagger$ & $+\ddagger$ & $+\$$ \\
\hline Oxidase & + & $+^{*}$ & $-\dagger$ & $+\ddagger$ & $-\S$ \\
\hline Growth at $4 \% \mathrm{NaCl}$ & - & $\mathrm{w}^{*}$ & $-\dagger$ & $+\ddagger$ & $-^{*}$ \\
\hline Cellulose hydrolysis & - & $+^{*}$ & $-\dagger$ & $-\ddagger$ & $-{ }^{*}$ \\
\hline \multicolumn{6}{|l|}{ Enzymic activities (API ZYM) } \\
\hline Cystine arylamidase & + & - & - & + & - \\
\hline Esterase (C4) & - & + & + & + & + \\
\hline Acid phosphatase & + & + & + & + & - \\
\hline$\alpha$-Mannosidase & + & - & - & - & - \\
\hline$\alpha$-Galactosidase & + & - & - & + & - \\
\hline$\beta$-Galactosidase & + & + & - & + & - \\
\hline$\alpha$-Glucosidase & + & + & + & + & - \\
\hline$\beta$-Glucosidase & + & + & + & + & - \\
\hline$N$-Acetyl- $\beta$-glucosaminidase & + & + & - & + & - \\
\hline$\alpha$-Fucosidase & + & + & - & - & - \\
\hline \multicolumn{6}{|c|}{ Biochemical characteristics (API 20NE) } \\
\hline Nitrate reduction & - & + & + & - & - \\
\hline Aesculin hydrolysis & + & + & - & + & - \\
\hline Gelatin hydrolysis & + & + & - & + & - \\
\hline$\beta$-Galactosidase & + & + & - & + & - \\
\hline \multicolumn{6}{|l|}{ Assimilation (API 20NE) } \\
\hline D-Mannose & + & + & + & + & - \\
\hline$N$-Acetylglucosamine & + & + & + & + & - \\
\hline Maltose & + & + & + & + & - \\
\hline Malate & - & + & - & - & - \\
\hline \multicolumn{6}{|c|}{ Acid production (API $50 \mathrm{CH}$ ) from: } \\
\hline Arbutin & + & - & - & - & - \\
\hline D-Mannose & - & + & + & + & + \\
\hline L-Arabinose & - & + & + & - & + \\
\hline D-Ribose & - & - & - & - & + \\
\hline D-Xylose & - & - & - & - & + \\
\hline D-Galactose & - & + & + & + & + \\
\hline D-Fructose & - & + & + & + & - \\
\hline Inositol & - & - & - & - & + \\
\hline Aesculin & + & + & + & + & - \\
\hline Cellobiose & - & - & + & - & - \\
\hline Maltose & - & - & + & - & - \\
\hline Trehalose & - & - & + & - & - \\
\hline Starch & - & - & + & - & - \\
\hline DNA G + C content $(\mathrm{mol} \%)$ & 66.6 & $63.8^{\star}$ & $63.4-64.0 \dagger$ & $63.0 \ddagger$ & $63.5 \$$ \\
\hline
\end{tabular}

${ }^{*}$ Data from An et al. (2005).

$\dagger$ Data from Xie \& Yokota (2005).

$\ddagger$ Data from Kim et al. (2006).

\$Data from Mergaert et al. (2002). 


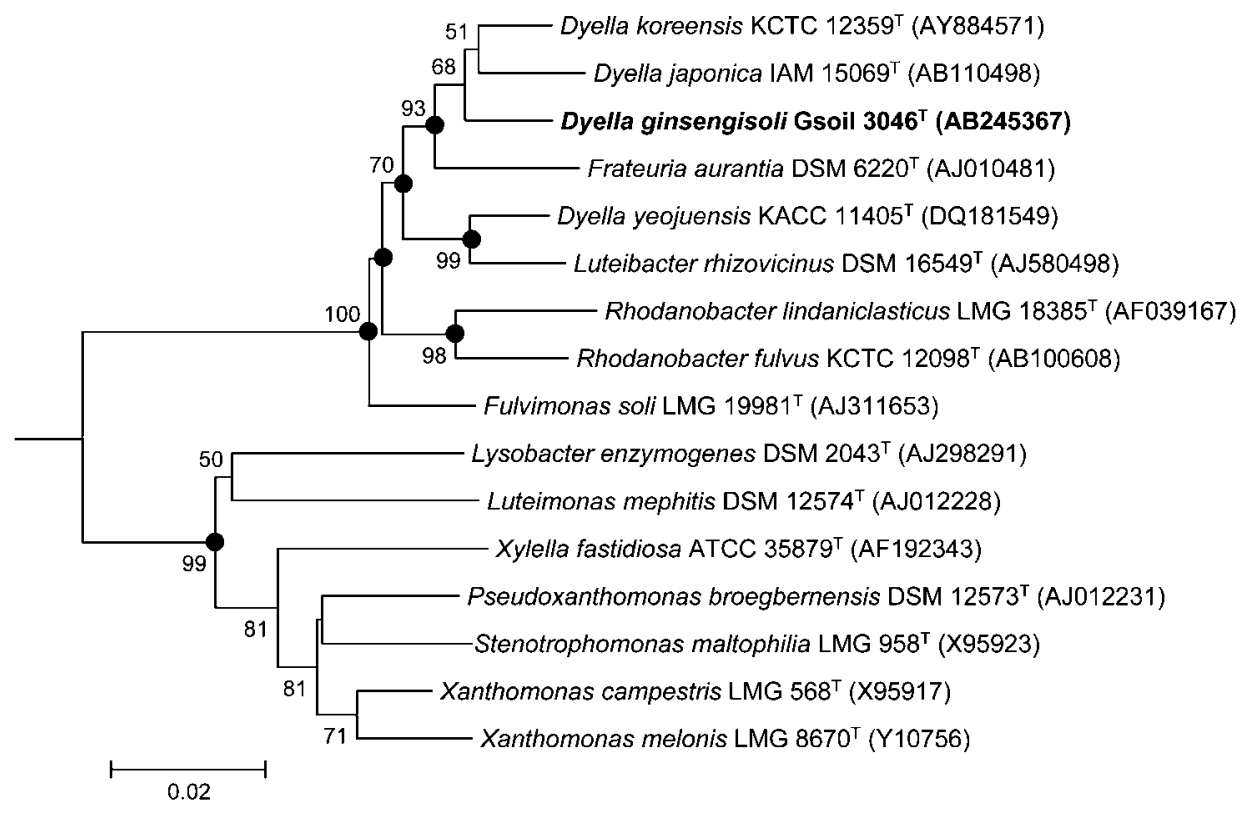

Fig. 1. Rooted neighbour-joining tree based on $16 \mathrm{~S}$ rRNA gene sequences of strain Gsoil $3046^{\top}$ and related type strains in the Gammaproteobacteria. GenBank accession numbers are shown in parentheses. Bootstrap percentages (based on 1000 replications) $>50 \%$ are shown at branch points. Filled circles indicate that the corresponding nodes were also recovered in

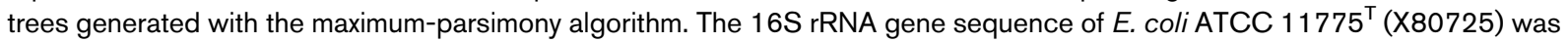
used as an outgroup (not shown). Bar, 0.02 substitutions per nucleotide position.

distances from other recognized species within the family Xanthomonadaceae, including D. yeojuensis KACC $11405^{\mathrm{T}}$, were greater than $4 \%$ (i.e. the sequence similarities were less than $96 \%$ ). It is generally accepted that strains with $<70 \%$ DNA-DNA relatedness (as measured by hybridization) or with $>3 \% 16 \mathrm{~S}$ rRNA gene sequence dissimilarity can be considered as belonging to separate species (Wayne et al., 1987; Stackebrandt \& Goebel, 1994). On the basis of these criteria, the data for strain Gsoil $3046^{\mathrm{T}}$ indicate that this strain represents a novel species of the genus Dyella. To verify the taxonomic position of strain Gsoil $3046^{\mathrm{T}}$, DNADNA hybridization was performed with its two closest relatives in the genus Dyella and with Frateuria aurantia.

DNA-DNA hybridization was performed fluorometrically according to the method of Ezaki et al. (1989), using photobiotin-labelled DNA probes (Sigma) and microdilution wells (Greiner), with five replications for each sample. The highest and lowest values obtained for each sample were excluded and the means of the remaining three values are quoted as the DNA-DNA hybridization values. Strain Gsoil $3046^{\mathrm{T}}$ exhibited relatively low levels of DNA-DNA relatedness with respect to $D$. koreensis KCTC $12359^{\mathrm{T}}$ $(24.8 \%)$, D. japonica IAM $15069^{\mathrm{T}}(18.5 \%)$ and Frateuria aurantia DSM $6220^{\mathrm{T}}(11.4 \%)$, indicating that it is not related to them at species level (Wayne et al., 1987; Stackebrandt \& Goebel, 1994).

The DNA G+C content of strain Gsoil $3046^{\mathrm{T}}$ was $66.6 \mathrm{~mol} \%$, which is slightly higher than the values reported for Dyella species (63.0-64.0 mol\%) (An et al., 2005; Xie \& Yokota, 2005; Kim et al., 2006). However, the value still lies within the range expected for members of the same genus and the $\mathrm{G}+\mathrm{C}$ content range of the genus Dyella should be extended to take account of the value obtained in our study. The cellular fatty acid profiles of isolate Gsoil $3046^{\mathrm{T}}$ and related strains are presented in Table 2. Strain Gsoil $3046^{\mathrm{T}}$ contained large amounts of isobranched and unsaturated iso-branched fatty acids such as iso- $\mathrm{C}_{17: 1} \omega 9 \mathcal{c}$, iso- $\mathrm{C}_{15: 0}$, iso- $\mathrm{C}_{16: 0}$ and iso- $\mathrm{C}_{17: 0}$, which are the major fatty acids found in members of the genus Dyella (Kim et al., 2006). The presence of iso- $\mathrm{C}_{13: 0} 3-\mathrm{OH}$ and iso$\mathrm{C}_{11: 0} 3-\mathrm{OH}$ as the major hydroxy fatty acids also supported the affiliation of strain Gsoil $3046^{\mathrm{T}}$ to the genus Dyella (Xie \& Yokota, 2005). However, some minor qualitative and quantitative differences in fatty acid content could be observed between strain Gsoil $3046^{\mathrm{T}}$ and its phylogenetically closest relatives. In particular, our strain differed from recognized Dyella species in possessing $\mathrm{C}_{17: 0}$ cyclo and containing less iso- $\mathrm{C}_{11: 0}$ 3-OH. Strain Gsoil $3046^{\mathrm{T}}$ contained ubiquinone Q-8 as the major respiratory quinone; this was also the case for recognized Dyella species (An et al., 2005; Xie \& Yokota, 2005; Kim et al., 2006).

All of the characteristics determined for strain Gsoil $3046^{\mathrm{T}}$ are in accordance with those of the genus Dyella. The phylogenetic distinctiveness of strain Gsoil $3046^{\mathrm{T}}$, together with the DNA-DNA hybridization data, confirmed that this strain represents a species that is distinct from the recognized Dyella species. There are some phenotypic 
Table 2. Cellular fatty acid profiles of strain Gsoil $3046^{\top}$ (Dyella ginsengisoli sp. nov.) and its phylogenetically closest relatives

Strains: 1 , Gsoil $3046^{\mathrm{T}}$ (data from this study); 2, D. koreensis KCTC $12359^{\mathrm{T}}$; 3, D. japonica IAM $15069^{\mathrm{T}}$; 4, D. yeojuensis KACC $11405^{\mathrm{T}} ; 5$, Frateuria aurantia DSM $6220^{\mathrm{T}}$. Data for taxa 2-5 are from Kim et al. (2006). All strains were grown on R2A agar at $30{ }^{\circ} \mathrm{C}$ for 48 h. -, Not detected or $<1 \%$ of total fatty acid content.

\begin{tabular}{|c|c|c|c|c|c|}
\hline Fatty acid & 1 & 2 & 3 & 4 & 5 \\
\hline \multicolumn{6}{|l|}{ Saturated } \\
\hline $\mathrm{C}_{14: 0}$ & - & - & - & - & 3.1 \\
\hline$C_{16: 0}$ & 3.4 & 2.5 & 1.5 & 1.8 & 7.5 \\
\hline $\mathrm{C}_{18: 0}$ & - & - & - & - & 1.2 \\
\hline iso- $\mathrm{C}_{11: 0}$ & 5.2 & 4.5 & 5.0 & 3.7 & - \\
\hline iso- $\mathrm{C}_{14: 0}$ & 1.0 & 1.1 & - & 1.1 & - \\
\hline iso- $\mathrm{C}_{15: 0}$ & 16.0 & 11.1 & 14.6 & 14.5 & 41.2 \\
\hline iso- $\mathrm{C}_{16: 0}$ & 16.1 & 19.2 & 17.5 & 21.3 & - \\
\hline iso- $\mathrm{C}_{17: 0}$ & 8.6 & 6.7 & 8.5 & 7.9 & 5.3 \\
\hline iso- $\mathrm{C}_{18: 0}$ & 1.0 & 2.6 & 1.3 & 1.2 & - \\
\hline anteiso- $\mathrm{C}_{15: 0}$ & 6.5 & 3.6 & 5.1 & 6.9 & 2.4 \\
\hline anteiso- $\mathrm{C}_{17: 0}$ & 1.5 & 2.9 & 1.8 & 1.6 & - \\
\hline $\mathrm{C}_{17: 0}$ cyclo & 2.4 & - & - & - & 9.8 \\
\hline \multicolumn{6}{|l|}{ Hydroxy } \\
\hline $\mathrm{C}_{12: 0} 2-\mathrm{OH}$ & - & - & - & - & 2.2 \\
\hline $\mathrm{C}_{12: 0} 3-\mathrm{OH}$ & - & - & - & - & 5.7 \\
\hline iso- $\mathrm{C}_{11: 0} 3-\mathrm{OH}$ & 1.3 & 5.5 & 6.0 & 4.2 & - \\
\hline iso- $\mathrm{C}_{12: 0} 3-\mathrm{OH}$ & 1.0 & 1.4 & 1.4 & 1.0 & - \\
\hline iso- $\mathrm{C}_{13: 0} 3-\mathrm{OH}$ & 3.4 & 2.3 & 4.0 & 2.4 & 1.2 \\
\hline iso- $\mathrm{C}_{17: 0} 3-\mathrm{OH}$ & - & - & 1.5 & - & - \\
\hline \multicolumn{6}{|l|}{ Unsaturated } \\
\hline $\mathrm{C}_{14: 1} \omega 5 c$ & - & - & - & - & 1.0 \\
\hline iso- $\mathrm{C}_{17: 1} \omega 9 c$ & 19.9 & 19.0 & 20.3 & 21.5 & 1.8 \\
\hline Unknown (ECL 11.799)* & 3.5 & 2.5 & 3.1 & 2.3 & - \\
\hline Summed feature $3 \dagger$ & 8.9 & 7.9 & 5.0 & 5.2 & 10.5 \\
\hline
\end{tabular}

${ }^{\star}$ ECL, Equivalent chain-length.

$\dagger$ Summed features are groups of two or three fatty acids that cannot be separated by GLC with the MIDI system. Summed feature 3 comprises iso- $\mathrm{C}_{15: 0} 2-\mathrm{OH}$ and/or $\mathrm{C}_{16: 1} \omega 7 c$.

differences between strain Gsoil $3046^{\mathrm{T}}$ and phylogenetically related Dyella species (Table 1). Therefore, on the basis of the data presented, strain Gsoil $3046^{\mathrm{T}}$ should be classified within the genus Dyella as representing a novel species, for which the name Dyella ginsengisoli sp. nov. is proposed.

\section{Description of Dyella ginsengisoli sp. nov.}

Dyella ginsengisoli (gin.seng.i.so'li. N.L. n. ginsengum ginseng; L. n. solum soil; N.L. gen. n. ginsengisoli of soil from a ginseng field, the source of the organism).

Cells are Gram-negative, aerobic, non-spore-forming, motile and rod-shaped $(0.2-0.5 \mu \mathrm{m}$ wide and $1.5-2.1 \mu \mathrm{m}$ long). $\mathrm{pH}$ range for growth is $5.0-8.5$. Tolerates $2 \%(\mathrm{w} / \mathrm{v})$ $\mathrm{NaCl}$, but not $3 \%$. Hydrolyses aesculin, gelatin and starch but not cellulose, chitin, DNA, xylan, skimmed milk or olive oil. The following substrates are utilized for growth: D-glucose, D-mannose, $\mathrm{N}$-acetylglucosamine, maltose, Dxylose, L-xylose, cellobiose, trehalose, glycogen, pyruvate, acetate, DL-3-hydroxybutyrate, valerate, L-glutamic acid and L-glutamine. The following substrates are not utilized for growth: D-galactose, D-lactose, D-fucose, ethanol, Lrhamnose, L-sorbose, D-arabinose, L-arabinose, D-lyxose, D-ribose, formate, propionate, caprate, maleate, fumarate, phenyl acetate, benzoate, 3-hydroxybenzoate, 4-hydroxybenzoate, salicin, citrate, lactate, malate, malonate, succinate, glutarate, tartrate, itaconate, adipate, suberate, oxalate, gluconate, D-adonitol, dulcitol, inositol, D-mannitol, Dsorbitol, xylitol, amygdalin, glycerol, methanol, inulin, dextran, L-alanine, L-arginine, L-asparagine, L-aspartic acid, L-cysteine, L-histidine, glycine, L-isoleucine, L-leucine, Llysine, L-methionine, L-phenylalanine, L-proline, L-serine, L-threonine, L-tryptophan, L-tyrosine and L-valine. Q-8 is the major isoprenoid quinone. Major fatty acids are iso$\mathrm{C}_{17: 1} \omega 9 c$, iso- $\mathrm{C}_{16: 0}$, iso- $\mathrm{C}_{15: 0}$ and iso- $\mathrm{C}_{17: 0}$. The $\mathrm{G}+\mathrm{C}$ content of the genomic DNA of the type strain is $66.6 \mathrm{~mol} \%$.

The type strain, Gsoil $3046^{\mathrm{T}}\left(=\mathrm{KCTC} 12599^{\mathrm{T}}=\mathrm{DSM}\right.$ $18387^{\mathrm{T}}$ ), was isolated from soil from a ginseng field in Pocheon Province, South Korea.

\section{Acknowledgements}

This work was supported by the 21C Frontier Microbial Genomics and Applications Center Program, Ministry of Education, Science \& Technology (Grant MG08-0101-2-0), Republic of Korea.

\section{References}

An, D.-S., Im, W.-T., Yang, H.-C., Yang, D.-C. \& Lee, S.-T. (2005), Dyella koreensis sp. nov., a $\beta$-glucosidase-producing bacterium. Int $J$ Syst Evol Microbiol 55, 1625-1628.

Atlas, R. M. (1993). Handbook of Microbiological Media. Edited by L. C. Parks. Boca Raton, FL: CRC Press.

Buck, J. D. (1982). Nonstaining (KOH) method for determination of Gram reactions of marine bacteria. Appl Environ Microbiol 44, 992-993.

Ezaki, T., Hashimoto, Y. \& Yabuuchi, E. (1989). Fluorometric deoxyribonucleic acid-deoxyribonucleic acid hybridization in microdilution wells as an alternative to membrane filter hybridization in which radioisotopes are used to determine genetic relatedness among bacterial strains. Int J Syst Bacteriol 39, 224-229.

Felsenstein, J. (1985). Confidence limits on phylogenies: an approach using the bootstrap. Evolution 39, 783-791.

Fitch, W. M. (1971). Toward defining the course of evolution: minimum change for a specific tree topology. Syst Zool 20, 406-416.

Hall, T. A. (1999). BioEdit: a user-friendly biological sequence alignment editor and analysis program for Windows 95/98/NT. Nucleic Acids Symp Ser 41, 95-98.

Hiraishi, A., Ueda, Y., Ishihara, J. \& Mori, T. (1996). Comparative lipoquinone analysis of influent sewage and activated sludge by highperformance liquid chromatography and photodiode array detection. J Gen Appl Microbiol 42, 457-469.

Im, W.-T., Jung, H.-M., Cui, Y.-S., Liu, Q.-M., Zhang, S.-L. \& Lee, S.-T. (2005). Cultivation of the three hundreds of bacterial species from the 
soil of the ginseng field and mining the novel lineage bacteria. In Proceedings of the International Meeting of the Federation of Korean Microbiological Societies, abstract A035, p. 169. Seoul: Federation of Korean Microbiological Societies.

Kim, M. K., Im, W.-T., Ohta, H., Lee, M. \& Lee, S.-T. (2005). Sphingopyxis granuli sp. nov., a $\beta$-glucosidase-producing bacterium in the family Sphingomonadaceae in $\alpha-4$ subclass of the Proteobacteria. J Microbiol 43, 152-157.

Kim, B.-Y., Weon, H.-Y., Lee, K.-H., Seok, S.-J., Kwon, S.-W., Go, S.-J. \& Stackebrandt, E. (2006). Dyella yeojuensis sp. nov., isolated from greenhouse soil in Korea. Int J Syst Evol Microbiol 56, 2079-2082.

Kimura, M. (1983). The Neutral Theory of Molecular Evolution. Cambridge: Cambridge University Press.

Kouker, G. \& Jaeger, K.-E. (1987). Specific and sensitive plate assay for bacterial lipases. Appl Environ Microbiol 53, 211-213.

Kumar, S., Tamura, K. \& Nei, M. (2004). MEGA3: integrated software for molecular evolutionary genetics analysis and sequence alignment. Brief Bioinform 5, 150-163.

Mergaert, J., Cnockaert, M. C. \& Swings, J. (2002). Fulvimonas soli gen. nov., sp. nov., a $\gamma$-proteobacterium isolated from soil after enrichment on acetylated starch plastic. Int J Syst Evol Microbiol 52, 1285-1289.

Mesbah, M., Premachandran, U. \& Whitman, W. B. (1989). Precise measurement of the $\mathrm{G}+\mathrm{C}$ content of deoxyribonucleic acid by highperformance liquid chromatography. Int J Syst Bacteriol 39, 159-167.

Moore, D. D. \& Dowhan, D. (1995). Preparation and analysis of DNA. In Current Protocols in Molecular Biology, pp. 2-11. Edited by F. M. Ausubel, R. Brent, R. E. Kingston, D. D. Moore, J. G. Seidman, J. A. Smith \& K. Struhl. New York: Wiley.

Nalin, R., Simonet, P., Vogel, T. M. \& Normand, P. (1999). Rhodanobacter lindaniclasticus gen. nov., sp. nov., a lindane-degrading bacterium. Int J Syst Bacteriol 49, 19-23.
Saitou, N. \& Nei, M. (1987). The neighbour-joining method: a new method for reconstructing phylogenetic trees. Mol Biol Evol 4, 406425.

Sasser, M. (1990). Identification of bacteria by gas chromatography of cellular fatty acids, MIDI Technical Note 101. Newark, DE: MIDI Inc.

Stackebrandt, E. \& Goebel, B. M. (1994). Taxonomic note: a place for DNA-DNA reassociation and $16 \mathrm{~S}$ rRNA sequence analysis in the present species definition in bacteriology. Int J Syst Bacteriol 44, 846849.

Swings, J., De Ley, J. \& Gillis, M. (1984). Genus III. Frateuria Swings, Gillis, Kersters, De Vos, Gosselé and De Ley, 1980, 547 ${ }^{\mathrm{VP}}$. In Bergey's Manual of Systematic Bacteriology, vol. 1, pp. 210-213. Edited by N. R. Krieg \& J. G. Holt. Baltimore: Williams \& Wilkins.

Ten, L. N., Im, W.-T., Kim, M.-K., Kang, M.-S. \& Lee, S.-T. (2004). Development of a plate technique for screening of polysaccharidedegrading microorganisms by using a mixture of insoluble chromogenic substrates. J Microbiol Methods 56, 375-382.

Ten, L. N., Baek, S.-H., Im, W.-T., Liu, Q.-M., Aslam, Z. \& Lee, S.-T. (2006). Bacillus panaciterrae sp. nov., isolated from soil of a ginseng field. Int J Syst Evol Microbiol 56, 2861-2866.

Thompson, J. D., Gibson, T. J., Plewniak, F., Jeanmougin, F. \& Higgins, D. G. (1997). The CLUSTAL_X windows interface: flexible strategies for multiple sequence alignment aided by quality analysis tools. Nucleic Acids Res 25, 4876-4882.

Wayne, L. G., Brenner, D. J., Colwell, R. R., Grimont, P. A. D., Kandler, O., Krichevsky, M. I., Moore, L. H., Moore, W. E. C., Murray, R. G. E. \& other authors (1987). International Committee on Systematic Bacteriology. Report of the ad hoc committee on reconciliation of approaches to bacterial systematics. Int J Syst Bacteriol 37, 463-464.

Xie, C. H. \& Yokota, A. (2005). Dyella japonica gen. nov., sp. nov., a $\gamma$ proteobacterium isolated from soil. Int J Syst Evol Microbiol 55, 753756. 